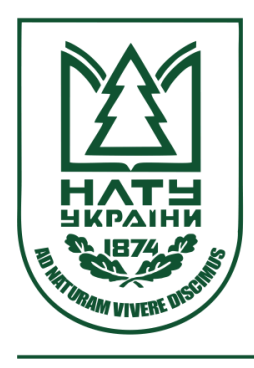

Науковий вісник НЛТУ України Scientific Bulletin of UNFU

https://nv.nltu.edu.ua

https://doi.org/10.15421/40290514

$@ \bowtie$ Correspondence author

Article received 15.05.2019 p.

Article accepted 30.05.2019 p.

V. B. Bychenko

УДК 630*52:582.632.2

В. Б. Биченко, В. В. Миронюк

Національний університет біоресурсів і природокористування України, м. Київ, Україна

\title{
ОСОБЛИВОСТІ МОДЕЛЮВАННЯ ТВІРНОЇ ПОВЕРХНІ СТОВБУРІВ ДУБА ЗВИЧАЙНОГО
}

\begin{abstract}
Узагальнено досвід дослідження форми стовбурів дерев, який дав змогу зробити висновок про переваги математичного моделювання твірної поверхні для аналізу збігу стовбурів. На основі дослідного матеріалу, зібраного в дубових насадженнях Придніпровського правобережного Лісостепу на 17 тимчасових пробних площах, проаналізовано залежність форми стовбурів дуба звичайного (Quercus robur L.) від висоти та діаметра на висоті 1,3 м. За допомогою графічного аналізу та $t$ тесту середніх значень коефіцієнтів форми Шиффеля на 5 \%-му рівні значущості виявлено відмінність у формі стовбурів дуба різних груп діаметрів. За розрядами висот статистично значущої різниці, за характером збігу не встановлено. Виконаний аналіз дав змогу обгрунтувати доцільність моделювання збігу стовбурів дуба звичайного незалежно від висоти, але в межах 3-х груп діаметрів: 20-28 см, 32-40 см та 44-64 см. Як моделі твірної поверхні стовбурів апробовано показниково-степеневі математичні рівняння A. Kozak (1988) i R. Newnham (1992). Підбір параметрів рівнянь виконано для вибірки 3171 модельного дерева в середовищі $\mathrm{R}$ за допомогою функції $n l s-$ нелінійна мінімізація суми квадратів відхилень. Систематична помилка обох рівнянь виявилася близькою до нуля (0,9-1,7 \%), що дало змогу прийняти їх для моделювання твірної поверхні стовбурів різної форми для встановлених груп діаметрів. Розроблені моделі дають змогу прогнозувати діаметри стовбурів дуба на будь-якій висоті зі стандартною помилкою 1,5-3,2 см. Все ж аналіз розподілу залишків математичних моделей засвідчив переваги моделі А. Kozak (1988), яку рекомендовано використовувати надалі для моделювання розмірно-якісної структури стовбурів дуба звичайного.
\end{abstract}

Ключові слова: форма стовбурів; збіг; рівняння твірної поверхні; біометричні показники; точність; адекватність.

Вступ. 3 огляду на теоретичну та практичну значущість, дослідженням форми стовбурів дерев традиційно приділяють значну увагу в науковій літературі. Ще М. Орлов (Orlov, 1929) зазначав, що, з огляду таксації та і взагалі всього лісівництва, деревний стовбур є найважливішим предметом дослідження, оскільки його формою й об'ємом визначається цінність продукції лісового господарства. Форма деревних стовбурів вкрай мінлива та залежить від багатьох чинників, що визначають умови росту дерева. Відомо, що стовбури на відкритих територіях формують збіжистий стовбур, тоді як у зімкнутих деревостанах - навпаки, досягають за однакових діаметрів вищої висоти, через що стають повнодеревнішими.

Дослідження форми та повнодеревності стовбурів тривало проводили 3 використанням коефіцієнтів форми $\left(q=d_{i} / d_{1,3}\right)$ А. Шиффеля та старого видового числа (Kershaw et al., 2016; Kofman, 1986). Зручність їхнього застосування полягає в можливості охарактеризувати форму стовбурів на основі невеликої кількості замірів, що дають змогу оцінити іï мінливість, залежність від певних чинників, а стовбури класифікувати за характером збігу. Ці показники створили основу для узагальнення форми стовбурів і донині найчастіше їх застосовують у прикладних дослідженнях та таксації лісу в Україні. Зокрема, чинні нормативи об'єму стовбурів ос- новних лісотвірних деревних видів України розробляли 3 використанням видового числа (Kashpor \& Strochynskyi, 2013; Svynchyk, Kashpor \& Myroniuk, 2014). Однак залежність цих показників від діаметра та висоти створює певні труднощі в отриманні об'єктивної оцінки форми стовбурів (Kershaw et al., 2016).

Основний недолік видового числа проявляється під час дослідження розмірної структури деревини, яку визначає збіг і характер твірної поверхні стовбура. 3 огляду на це, у лісовій таксації з'явилося багато інших альтернативних підходів. Захаров В. К. Zakharov, (1955 р.) дослідив форми стовбурів сосни, які зростали в різних умовах, 3 використанням чисел збігу $\left(\eta_{i}=d_{i} / d_{0,1}\right)$ та обгрунтував, що значення $\eta_{i}$ не залежать від ступеня товщини, висоти та умов місцезростання $\left(\eta_{i}=\right.$ const). На підставі цього вчений висунув гіпотезу про подібність форми стовбурів певного деревного виду та запропонував нову методику побудови об'ємних таблиць, за якою використовують середні значення абсолютного збігу для обчислення видових чисел та об'єму стовбурів. Пізніше виявлено обмеження у застосуванні висунутої гіпотези. Зокрема, грунтовний аналіз різних підходів до узагальнення форми стовбурів провів Г. Б. Кофман (Kofman, 1986) і довів, що числа збігу залежать не тільки від діаметра стовбура, а й частково від висоти та інших формоутворювальних чинників. Незважаючи на

Інформація про авторів:

Биченко Володимир Борисович, здобувач, кафедра таксації лісу та лісового менеджменту. Email: vladimirbb@i.ua

Миронюк Віктор Валентинович, канд. с.-г. наук, доцент, кафедра таксації лісу та лісового менеджменту.

Email: victor.myroniuk@nubip.edu.ua; https://orcid.org/0000-0002-5961-300X

Цитування за ДСТУ: Биченко В. Б., Миронюк В. В. Особливості моделювання твірної поверхні стовбурів дуба звичайного. Науковий вісник НлтУ України. 2019, т. 29, № 5. С. 69-74.

Citation APA: Bychenko, V. B., \& Myroniuk, V. V. (2019). Some peculiarities of stem taper modelling of common oak trees. Scientific Bulletin of UNFU, 29(5), 69-74. https://doi.org/10.15421/40290514 
це, подібні до ідеї В. К. Захарова методики продовжують застосовуватися на практиці (Socha, 2002).

Аналіз літературних джерел останнього десятиріччя свідчить, що більшість досліджень форми стовбурів пов'язані з моделюванням їх твірної поверхні (Fonweban et al., 2011; Li \& Weiskittel, 2010; Poudel, Temesgen \& Gray, 2018). Нині для характеристики збігу деревних стовбурів використовуються різні типи математичних рівнянь, які дають змогу з високою точністю визначити об'єм як усього стовбура, так і його окремих частин (Burkhart \& Tomé, 2012). Науковий доробок учених у цьому напрямі виявився найбільш важливим для опрацювання ефективних методів прогнозування розмірноякісних показників ділових лісоматеріалів (Barrio Anta, Diéguez-Aranda, Castedo-Dorado, Álvarez González \& von Gadow, 2007; Fonweban, Gardiner \& Auty, 2012).

Очевидно, що найточніше форма стовбура може бути виражена рівнянням твірної поверхні, яке дає змогу визначити діаметр стовбура на будь-якій висоті. Зазвичай прогнозування прийнято виконувати для стовбурів середньої форми, з огляду на що в окремих випадках будуть виникати істотні відхилення. Більшої точності математичних моделей можна досягти, згрупувавши їх залежно від збігу стовбурів різних розмірів. Отже, у представленій роботі опрацьовано систему математичних моделей твірної поверхні стовбурів дуба звичайного, враховуючи особливості впливу біометричних показників дерев на їхню форму.

Мета дослідження - обгрунтувати методику моделювання збігу стовбурів дуба звичайного різної форми, підібрати параметри математичних моделей твірних поверхонь і за результатами аналізу точності та адекватності визначити кращу з отриманих моделей.

Матеріал і методи дослідження. Первинні дослідні дані отримали за результатами обміру 171-го модельного дерева дуба (МД) на 17-ти тимчасових пробних площах у дубових деревостанах Придніпровського правобережного Лісостепу. Тимчасові пробні площі закладали у пристиглих, стиглих та перестиглих дубових насадженнях, які рівномірно розміщені в регіоні досліджень. Із метою моделювання збігу на зрубаному дереві визначали такі показники: довжину стовбура від пня, висоту пня, діаметри в корі та товщину кори на окоренковому зрізі, висоті грудей і на серединах 2-метрових секцій. Обробляли дані з використанням табличного процесора MS Excel, програми ПЕРТА кафедри таксації лісу та лісового менеджменту НУБіП України та за алгоритмами, розробленими у статистичній системі $\mathrm{R}(R$ Core Team, 2018). Основні статистики розподілу біометричних показників стовбурів МД ( $d_{1,3}$ - діаметр у корі на висоті $1,3 \mathrm{~m} ; h$ - висота; $f$ - старе видове число, $q_{2}$ - коефіцієнт форми, $q_{0,5}-$ клас форми) навели у табл. 1.

Розподіл кількості модельних дерев за діаметром на висоті грудей та висотою охоплює досить широкий діапазон. Кожен ступінь товщини представлений модельними деревами різних висот. Такий розподіл дослідного матеріалу охоплює I-IV розряди висот деревостанів (Kashpor \& Strochynskyi, 2013) та свідчить про репрезентативність вибірки.

Аналізуючи наведені статистичні показники (див. табл. 1), існують підстави стверджувати, що розподіли модельних дерев за діаметром, висотою та видовим числом наближаються до нормального. Про це свідчать значення асиметрії та ексцесу, стосовно яких виконуються такі умови (Nikitin \& Shvidenko, 1978):

$$
\begin{aligned}
& |A| \cdot m_{A}{ }^{-1}<2, \\
& |E| \cdot m_{E}{ }^{-1}<2,
\end{aligned}
$$

де: $A, E$ - відповідно асиметрія та ексцес, $m_{A}, m_{E}-$ відповідно помилки асиметрії та ексцесу.

Табл. 1. Таксаційні показники модельних дерев

і їх статистики

\begin{tabular}{|c|c|c|c|c|c|}
\hline \multirow{2}{*}{$\begin{array}{c}\text { Статисти- } \\
\text { ка }^{1}\end{array}$} & \multicolumn{5}{|c|}{ Таксаційний показник } \\
\cline { 2 - 6 } $\max$ & $d_{1,3}, \mathrm{~cm}$ & $h, \mathrm{M}$ & $f$ & $q_{2}$ & $q_{0,5}$ \\
\hline $\min$ & 65,7 & 33,5 & 0,614 & 0,867 & 0,903 \\
\hline$M$ & 20,2 & 18,3 & 0,389 & 0,491 & 0,527 \\
\hline$\sigma$ & 38,3 & 24,9 & 0,506 & 0,732 & 0,785 \\
\hline$v$ & 10,2 & 2,5 & 0,043 & 0,061 & 0,061 \\
\hline$A$ & 26,7 & 10,0 & 8,5 & 8,4 & 7,8 \\
\hline$E$ & 0,330 & 0,131 & $-0,141$ & $-1,308$ & $-1,675$ \\
\hline
\end{tabular}

Пояснення: ' $\max , \min$ - максимальне та мінімальне значення; $M)$ середнє арифметичне значення; $\sigma$ ) середньоквадратичне відхилення; v) коефіцієнт варіації, \%; $A$ ) асиметрія; $E$ ) ексцес

За таких умов, перевірку статистичних гіпотез під час аналізу та оброблення дослідних даних доцільно виконувати на основі параметричних критеріїв.

Результати дослідження. Пошук математичної моделі та обчислення іiі параметрів для одного стовбура сьогодні не вважається складним завданням. Напрацьований досвід та програмні засоби дають змогу з високою точністю описати певним рівнянням форму конкретного стовбура. Як видно 3 табл. 1, за розмахом та коефіцієнтом варіації видового числа, другого коефіцієнта та класу форми, стовбури мають значну природну мінливість. Зазначене створює передумови для розробки окремих моделей збігу за певними групами стовбурів, які схожі за формою. Враховуючи взаємозв'язок значень показників форми та повнодеревності з біометричними показниками дерев (Kofman, 1986), виділяти такі групи доречно за висотою або діаметром стовбурів.

Для виявлення відмінностей залежно від висоти модельні дерева згруповано за розрядами висот чинних нормативів (Kashpor \& Strochynskyi, 2013), для яких обчислено середні значення коефіцієнтів форми. Гіпотезу про відмінність форми стовбурів з різними значеннями діаметра на висоті 1,3 м проаналізували на основі середніх значень коефіцієнтів форми модельних дерев за групами діаметрів: $20-28$ см, 32-40 см, 44-52 см та 5664 см. Графічний вигляд форми стовбурів у відносних координатах для утворених груп зображено на рис. 1.

3 рис. 1,a простежуємо, що твірні стовбурів за розрядами висот майже збігаються від окоренка до відносної висоти 0,6 h, після якої з'являється певна диференціація у верхівковій частині. Графічний аналіз форми стовбурів дуба різних груп діаметрів (рис. 1,б) свідчить, що істотна різниця у формі стовбурів починається з відносної висоти 0,2h, яка може відобразитись надалі на точності визначення їхніх об'ємів.

3 метою статистичної оцінки відмінностей у формі стовбурів різних груп (як за висотою, так і за діаметром) проведено попарний $t$-тест для коефіцієнтів форми та видових чисел. На 5 \%-му рівні значущості встановлено відсутність відмінностей між показниками форми МД за висотою. Водночас значущу відмінність спостерігаємо між усіма групами діаметрів, окрім попарної комбінації груп 44-52 см і 56-64 см. Отже, за результатами графічного та статистичного аналізу доцільно про- 
вести моделювання твірної поверхні стовбурів дуба незалежно від висоти, але в межах 3-х груп діаметрів: 20 28 см, 32-40 см та 44-64 см.
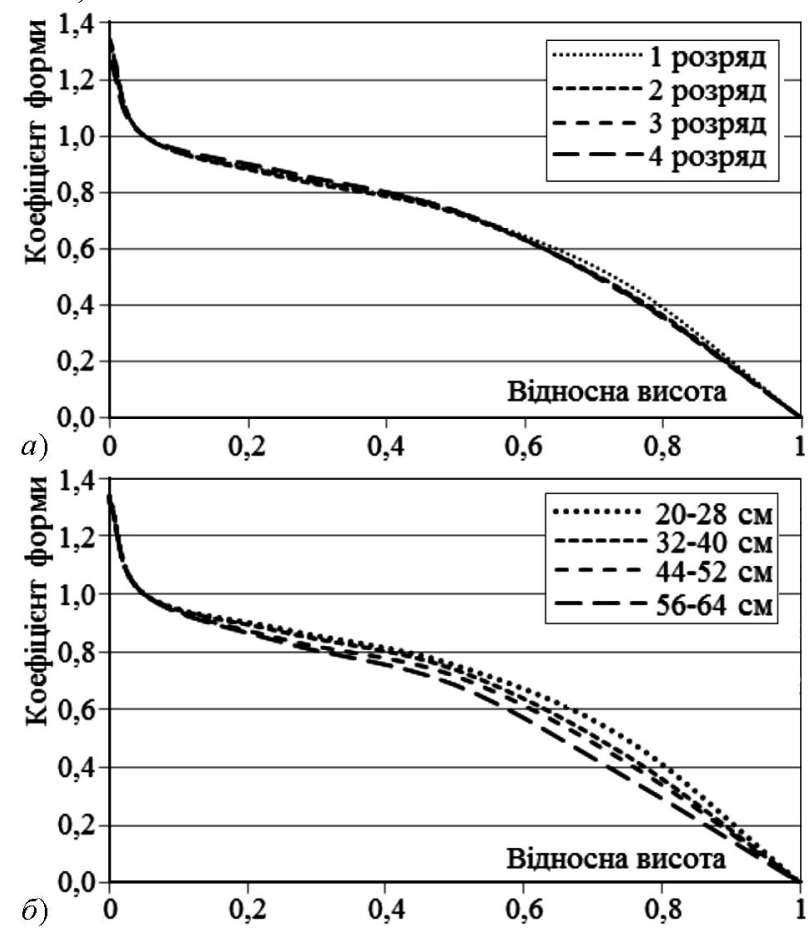

Рис. 1. Форма стовбурів дуба звичайного: $a$ ) залежно від висоти, б) залежно від діаметра

Досвід моделювання твірної поверхні свідчить, що українські вчені здебільшого застосовували для цього метод зональної апроксимації та відносно прості функції (степеневі, показникові та поліноми різних порядків). Розроблені за кордоном моделі твірної поверхні це комплексні алометричні функції, які коректно відображають збіг діаметра на різних ділянках стовбура. У наших дослідженнях (табл. 2) проаналізували дві математичні моделі, що широко апробували на практиці різні вчені за кордоном (Kozak, 1988; Newnham, 1992).

Табл. 2. Математичні моделі твірної поверхні

\begin{tabular}{|c|c|c|}
\hline Автор, рік & Математичний вираз моделі ${ }^{1}$ & $\begin{array}{c}\text { № рів- } \\
\text { няння }\end{array}$ \\
\hline $\begin{array}{c}\text { R. Newnham, } \\
1992\end{array}$ & \begin{tabular}{c}
$d_{i}=d \cdot X^{\left(a_{0}+a_{1}(z-1)+a_{2} \cdot \exp \left(a_{3} z\right)\right)} ;$ \\
\hline $\begin{array}{c}\text { A. Kozak, } \\
1988\end{array}$
\end{tabular} & $\left.\begin{array}{c}\left.d_{i}=a_{0} \cdot d^{a_{1}} \cdot a_{2}^{d} \cdot X^{\left(b_{1} z^{2}+b_{2} \cdot \ln (z+0.001)+b_{3} \cdot \sqrt{z}+b_{4} \cdot \exp (z)+b_{5}\right.} \cdot \frac{d}{h}\right) \\
X=\left(1-\sqrt{h_{i} / h}\right) /(1-\sqrt{0,1225}) ; z=h_{i} / h\end{array}\right)$ (4) \\
\hline
\end{tabular}

Пояснення: ${ }^{1} d_{i}-$ діаметр стовбура на висоті $h_{i} ; d-$ діаметр стовбура на висоті 1,30 м; $h$ - загальна висота стовбура; $a, b-$ параметри.

Для пошуку параметрів рівняння (3) існує можливість аналізу збігу стовбурів у відносній системі координат. Так, діаметр на висоті грудей $(d)$ входить у формулу лінійно, тому, перенісши його в ліву частину, отримаємо математичну модель для відносного діаметра $d_{i} / d$. Оскільки мінливість відносних діаметрів, встановлених на відносних висотах, виявляється меншою від абсолютних, з'являються передумови для підвищення загальної точності апроксимації. Підбір параметрів математичної моделі (4) виконували для абсолютних значень діаметрів і висоти стовбурів дуба.

Представлені у табл. 2 математичні моделі - це показниково-степеневі рівняння, тобто рівняння нелі- нійного виду. Як відомо (Nikitin \& Shvidenko, 1978), пошук параметрів таких рівнянь потребує застосування складніших чисельних методів, ніж для лінійних. Сьогодні в багатьох мовах програмування закладено готові алгоритми регресійного аналізу. Зокрема, підбір параметрів для рівнянь (3-4) виконано у середовищі $R$ за допомогою функції $n l s$, яка використовує нелінійну мінімізацію суми квадратів відхилень на основі методу Ньютона. Отримані в такий спосіб параметри наведено у табл. 3.

Табл. 3. Параметри математичних моделей твірної поверхні стовбурів дуба звичайного

\begin{tabular}{|c|c|c|c|c|c|c|}
\hline \multirow{2}{*}{$\begin{array}{c}\text { Коефi- } \\
\text { цієнт }\end{array}$} & \multicolumn{6}{|c|}{ Значення коефіціснтів рівнянь (3-4) залежно від гру- } \\
& $20-28$ & $32-40$ & $44-64$ & $20-28$ & $32-40$ & $44-64$ \\
\hline- & \multicolumn{2}{|c|}{ R. Newnham (3) } & \multicolumn{4}{c|}{ A. Kozak (4) } \\
\hline$a_{0}$ & 0,5918 & 0,6971 & 0,7787 & 0,02291 & 2,776 & 0,2607 \\
\hline$a_{1}$ & 0,2567 & 0,4046 & 0,4546 & 2,691 & 0,5510 & 1,466 \\
\hline$a_{2}$ & 5,708 & 6,140 & 6,427 & 0,9334 & 1,014 & 0,9888 \\
\hline$a_{3}$ & $-17,86$ & $-16,23$ & $-14,03$ & - & - & - \\
\hline$b_{1}$ & - & - & - & 1,928 & 1,946 & 1,260 \\
\hline$b_{2}$ & - & - & - & $-0,4467$ & $-0,4056$ & $-0,3293$ \\
\hline$b_{3}$ & - & - & - & 2,781 & 2,286 & 1,217 \\
\hline$b_{4}$ & - & - & - & $-1,575$ & $-1,387$ & $-0,6096$ \\
\hline$b_{5}$ & - & - & - & 0,1018 & 0,1359 & $-0,03341$ \\
\hline \multicolumn{7}{c}{} \\
\hline
\end{tabular}

Обговорення результатів дослідження. Порівняння фактичних даних замірів діаметрів модельних дерев 3 результатами їхньої оцінки за математичними моделями твірної поверхні графічно відображено на рис. 2. Відповідно до одержаного прогнозу твірні стовбурів дуба, згідно з рівнянням (3), приблизно до відзначки 10-12 м менш збіжисті, ніж за моделлю (4). Ця модель також прогнозує більший збіг стовбурів в окоренку. Форма стовбурів у верхній частині за одержаними рівняннями практично не відрізняється. Враховуючи подібність опрацьованих математичних моделей, грунтовніші висновки про їхню точність отримано на основі статистичного аналізу.

Насамперед для оцінки адекватності розроблених математичних моделей обчислено низку показників точності апроксимації. Вони характеризують ступінь відповідності змодельованих і фактичних значень діаметрів у корі для відзначок, за якими обмірювали стовбури модельних дерев (по середині двометрових секцій), а їхні значення навели в табл. 4:

- систематична похибка:

$$
u=\frac{1}{n} \cdot \sum_{i=1}^{n}\left(\hat{y}_{i}-y_{i}\right)
$$

• систематична відносна похибка:

$$
u \%=\frac{1}{n} \cdot \sum_{i=1}^{n} \frac{\hat{y}_{i}-y_{i}}{y_{i}} \cdot 100 \%
$$

• абсолютна похибка:

$$
|u|=\frac{1}{n} \cdot \sum_{i=1}^{n}\left|\hat{y}_{i}-y_{i}\right|
$$

- стандартна похибка моделювання:

$$
s=\sqrt{\frac{\sum_{i=1}^{n}\left(\hat{y}_{i}-y_{i}\right)^{2}}{n-k-1}} ;
$$

• коефіцієнт детермінації:

$$
R^{2}=1-\frac{\sum_{i=1}^{n}\left(\hat{y}_{i}-y_{i}\right)^{2}}{\sum_{i=1}^{n}\left(y_{i}-\bar{y}\right)^{2}},
$$


де: $y_{i}$ - фактичне значення діаметра, см; $\hat{y}_{i}-$ розрахункове значення діаметра, см; $\bar{y}-$ середнє фактичне зна- чення діаметра, см; $n$ - кількість спостережень; $k$ - кількість незалежних змінних у математичній моделі.
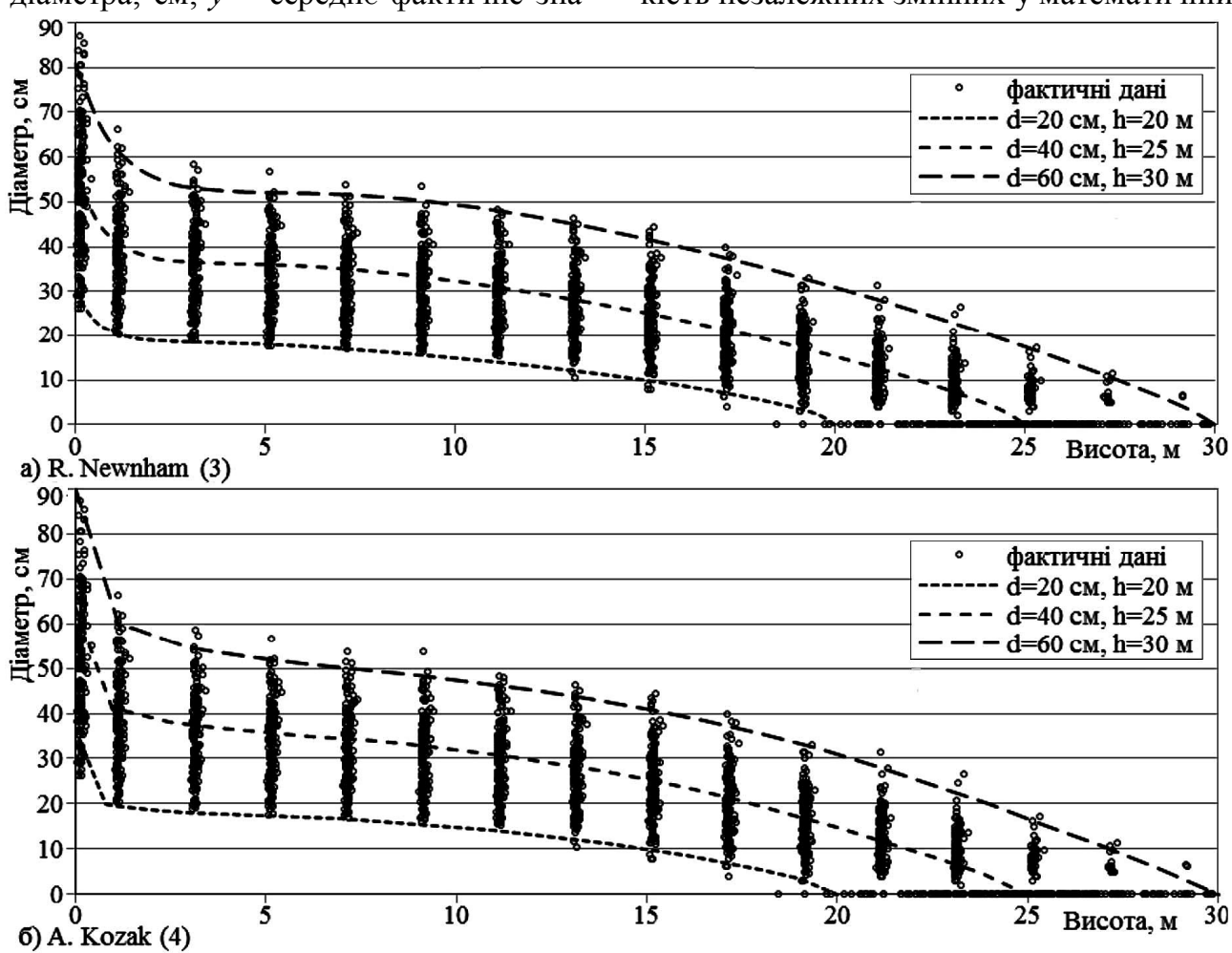

Pис. 2. Фактичні та змодельовані значення діаметрів стовбурів дуба звичайного залежно від висоти стовбурів

У наших дослідженнях приймалося $k=3$, оскільки як аргументи до моделей твірної поверхні стовбурів входять три змінні: діаметр на висоті грудей, загальна висота та висота $i$-тої точки на стовбурі.

Табл. 4. Оцінки показників точності математичних моделей

\begin{tabular}{|c|c|c|c|c|c|c|}
\hline \multirow{2}{*}{$\begin{array}{c}\text { Ста- } \\
\text { тисти- }\end{array}$} & \multicolumn{6}{|c|}{ Значення статистики за групою діаметрів та рівнянням } \\
\cline { 2 - 7 } ка & $\begin{array}{c}\text { R. Newn } \\
\text { ham (3) }\end{array}$ & $\begin{array}{c}\text { A. Ko- } \\
\text { zak (4) }\end{array}$ & $\begin{array}{c}\text { R. Newn } \\
\text { ham (3) }\end{array}$ & $\begin{array}{c}\text { A. Ko- } \\
\text { zak (4) }\end{array}$ & $\begin{array}{c}\text { R. Newn } \\
\text { ham (3) }\end{array}$ & $\begin{array}{c}\text { A. Ko- } \\
\text { zak (4) }\end{array}$ \\
\hline$u$, cм & 0,06 & 0,00 & 0,03 & $-0,03$ & 0,02 & $-0,04$ \\
\hline$u \%$ & 1,4 & 1,0 & 1,8 & 1,2 & 1,7 & 0,9 \\
\hline$|u|, \mathrm{cm}$ & 1,03 & 0,94 & 1,45 & 1,38 & 2,18 & 2,15 \\
\hline$s, \mathrm{~cm}$ & 1,52 & 1,40 & 2,11 & 2,02 & 3,19 & 3,21 \\
\hline$R^{2}$ & 0,972 & 0,977 & 0,973 & 0,975 & 0,967 & 0,967 \\
\hline
\end{tabular}

Виконаний аналіз свідчить, що систематична похибка $(u)$ для обох моделей наближається до нуля. Систематична відносна похибка ( $u$ \%) дещо менша для моделі A. Kozak (4), хоча за абсолютною $(|u|)$ та стандартною $(s)$ похибками моделювання обох мають незначні відмінності. Аналогічно, незначні відмінності спостерігаємо для коефіцієнта множинної детермінації- для обох моделей його значення близьке до одиниці та вказує на достатню точність рівнянь загалом. За обчисленими статистиками можна зробити висновок, що всі моделі мають достатню точність прогнозування зміни діаметра стовбура з висотою.

На наступному етапі перевірки якості рівнянь твірної поверхні проаналізували розподіл залишків моделювання. Відомо, що для адекватних моделей відсутня автокореляція залишків, їхня величина не залежить від змінних, а розподіл абсолютних величин наближається до нормального (Nikitin \& Shvidenko, 1978). Достатне уявлення про залежність залишків від чинників рівняння можна одержати за графіками, на яких величина абсолютних відхилень за діаметром відображена відповідно до відносних значень висоти стовбурів $\left(h_{i} / h\right)$. На основі цього проявляється зв'язок залишків моделювання одночасно від незалежних змінних (діаметра на висоті грудей, загальної висоти стовбура, висоти $i$-тої точки на стовбурі) та залежної змінної (діаметра $i$-тої точки) рівняння. Для прикладу, на рис. 3 зображено розподіли залишків моделювання для стовбурів завтовшки $32-40 \mathrm{~cm}$
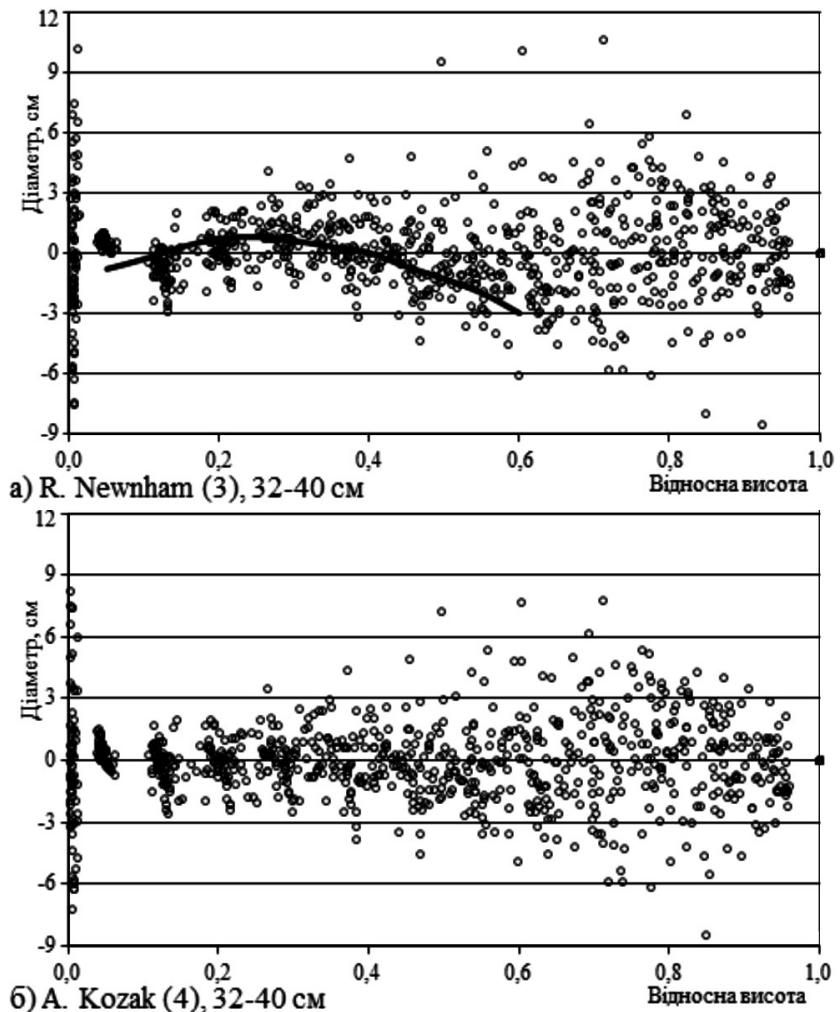

Рис. 3. Залишки рівнянь твірної поверхні стовбурів дуба залежно від відносної висоти (суцільною лінією відображено локально зважене згладжування) 
Графічний аналіз довів, що по осі ординат залишки обох моделей для всіх груп діаметрів розподілені рівномірно, тобто додатні та від'ємні значення компенсують один одного. Це підтверджує значення систематичної похибки $(u)$, яка наближається до нуля. За відносною висотою для всіх моделей прослідковується збільшення абсолютної величини залишків, що пояснюємо природною мінливістю діаметрів у верхівці стовбура.

Після докладного дослідження рис. 3 помітно, що для моделі (3) у нижній частині стовбура простежуємо характерну тенденцію розподілу залишків (позначена на графіку лінією), що може свідчити про їхню автокореляцію, тобто зв'язок зі значеннями відгуку, який виникає внаслідок лагової залежності значень випадкової величини в різних спостереженнях. Однією 3 причин цього може бути відсутність у моделі вагомого чинника або неправильний вибір форми зв'язку. 3 деякою точністю оцінити ступінь автокореляції можливо за допомогою $d$-критерію Дарбіна-Уотсона (Johnston, 1980), який розраховуємо за формулою

$$
d=\frac{\sum_{i=2}^{n}\left(e_{i}-e_{i-1}\right)^{2}}{\sum_{i=1}^{n} e_{i}^{2}},
$$

де: $n$ - кількість спостережень, $e_{i}-$ відхилення (залишок) фактичного значення діаметра у $i$-тій точці стовбура від розрахункового.

Якщо у залишках існує повна позитивна автокореляція, то $d=0$, при повній від'ємній автокореляції $d=4$ i якщо автокореляція відсутня, то $d=2$. Для заданого числа спостережень $n$, числа незалежних змінних $k$ у рівнянні регресії та рівня значущості $\alpha$ існують критичні значення $d_{L}$ та $d_{U}$. Ці значення поділяють числовий відрізок [0; 4] на п'ять проміжків. У разі попадання фактичного значення $d$ у той чи інший проміжок, гіпотеза про відсутність автокореляції: $\left[0 ; d_{L}\right]-$ спростовується (наявність додатної автокореляції), $\left[d_{L} ; d_{U}\right]-$ зона невизначеності (немає підстав ні підтвердити, ні відхилити гіпотезу), $\left[d_{U} ; 4-d_{U}\right]-$ підтверджується, $\left[4-d_{U} ; 4-d_{L}\right]-$ зона невизначеності, [4- $\left.{ }_{L} ; 4\right]-$ спростовується (наявність від'ємної автокореляції). Оскільки існують дві зони невизначеності, критерій Дарбіна-Уотсона дає достовірні результати тільки для великих за обсягом вибірок $(n>30)$. Зі збільшенням $n$, критичні значення $d_{L}$ та $d_{U}$ наближаються один до одного, а зони невизначеності скорочуються.

Тест автокореляції залишків моделей за критерієм Дарбіна-Уотсона проведено для нижньої частини стовбура $(0-0,5 h)$, де іiі найбільш помітно. Для цього усереднено значення залишків моделювання за висотою із градацією через $0,01 h$. За формулою (10), для отриманого ряду середніх значень, розрахували фактичні значення $d$, а за таблицями розподілу (Johnston, 1980) знайшли критичні значення $d_{L}$ та $d_{U}$ (для рівня значущості $\alpha=0,05)$. У табл. 5 навели результати обчислень та зони, у які попадають фактичні значення $d$. Аналізуючи дані цієї таблиці, гіпотеза про відсутність автокореляції залишків (за рівня значущості 0,05) підтверджується для моделі A. Kozak (4) у всіх групах, а для R. Newnham (3) - тільки для групи діаметрів 20-28 cм. Форму розподілу абсолютних величин залишків моделювання оцінили за допомогою графіків. На рис. 4, для наочності, навели розподіли для групи діаметрів 44$64 \mathrm{~cm}$.
Табл. 5. Результати тесту автокореляції залишків моделей твірної поверхні стовбурів дуба за критерісм Дарбіна-Уотсона

\begin{tabular}{|c|c|c|c|c|c|c|}
\hline \multirow[b]{2}{*}{ Рівняння } & \multicolumn{6}{|c|}{$\begin{array}{c}\text { Значення критичних та фактичного критерію } \\
\text { за рівнянням та групою діаметрів } \\
\end{array}$} \\
\hline & $\begin{array}{c}\text { додат- } \\
\text { ня ав- } \\
\text { токоре- } \\
\text { ляція } \\
\end{array}$ & $d_{L}$ & $\begin{array}{c}\text { зона не- } \\
\text { визначе- } \\
\text { ності }\end{array}$ & $d_{U}$ & \begin{tabular}{|c} 
відсут- \\
ність ав- \\
токоре- \\
ляції
\end{tabular} & $4-d_{U}$ \\
\hline \multicolumn{7}{|c|}{$20-28 \mathrm{~cm}$} \\
\hline R. Newnham (3) & - & \multirow{2}{*}{1,399} & - & \multirow{2}{*}{1,603} & 1,974 & \multirow{2}{*}{2,397} \\
\hline A. Kozak (4) & - & & - & & 2,022 & \\
\hline \multicolumn{7}{|c|}{$32-40 \mathrm{~cm}$} \\
\hline $\begin{array}{l}\text { R. Newnham } \\
\text { (3) }\end{array}$ & 1,037 & \multirow[t]{2}{*}{1,430} & - & \multirow[t]{2}{*}{1,615} & - & \multirow[t]{2}{*}{2,385} \\
\hline A. Kozak (4) & - & & - & & 1,858 & \\
\hline \multicolumn{7}{|c|}{$44-64 \mathrm{~cm}$} \\
\hline R. Newnham (3) & 0,928 & \multirow{2}{*}{1,436} & - & \multirow{2}{*}{1,618} & - & \multirow{2}{*}{2,382} \\
\hline A. Kozak (4) & - & & - & & 1,866 & \\
\hline
\end{tabular}

Наведені графіки (див. рис. 4) дають підстави стверджувати, що розподіл відхилень для моделі (4) найбільш наближений до нормального. Для моделі (3) графік (рис. 4,a) має виражену гостровершинність та несиметричність на краях розподілу.
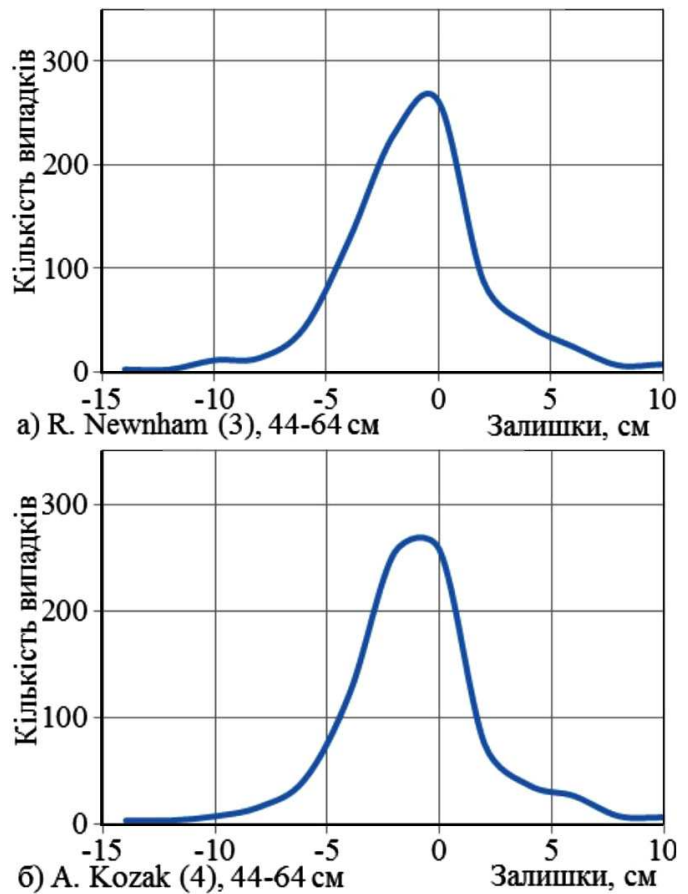

Рис. 4. Розподіл залишків моделей твірної поверхні стовбурів дуба

Проведений аналіз математичних моделей твірної поверхні стовбурів дуба за точністю та адекватністю обгрунтовує застосування рівняння A. Kozak (4) для обчислення об'єму та подальшого розроблення нормативів розмірно-якісної структури деревини.

Висновки. На основі виконаних досліджень можна зробити три основних висновки, що визначають особливості моделювання форми стовбурів дерев дуба звичайного.

1. За аналізом середніх коефіцієнтів форми виявлено відмінність у формі стовбурів дуба різних груп діаметрів. Статистична оцінка за допомогою $t$-тесту, на $5 \%$-му рівні значущості, підтвердила наявність певних відмінностей. За висотою (розрядами висот) значущої відмінності не виявлено. Моделювання твірної поверхні доцільно виконувати незалежно від висоти, але за групами діаметрів. 
2. Математичні моделі A. Kozak (4) та R. Newnham (3), опрацьовані за трьома групами діаметрів стовбурів, засвідчили досить високу точність (систематична похибка становить 0,9-1,7\%). Одержані рівняння для встановлених груп діаметрів здатні ефективно відображати збіг стовбурів різної форми.

3. Оцінка адекватності дає підстави стверджувати, що серед розглянутих точнішою виявилася математична модель A. Kozak (4). Цю функцію доцільно застосувати для подальшого моделювання розмірно-якісної структури стовбурів дуба звичайного.

\section{Перелік використаних джерел}

Barrio Anta, M., Diéguez-Aranda, U., Castedo-Dorado, F., Álvarez González, J. G., \& von Gadow, K. (2007). Merchantable volume system for pedunculate oak in northwestern Spain. Annals of Forest Science, 64(5), 511-520. https://doi.org/10.1051/forest:2007028

Burkhart, H. E., \& Tomé, M. (2012). Modeling Forest Trees and Stands. https://doi.org/10.1007/978-90-481-3170-9

Fonweban, J., Gardiner, B., \& Auty, D. (2012). Variable-top merchantable volume equations for Scots pine (Pinus sylvestris) and Sitka spruce (Picea sitchensis (Bong.) Carr.) in Northern Britain. Forestry, 85(2), 237-253. https://doi.org/10.1093/forestry/cpr069

Fonweban, J., Gardiner, B., Macdonald, E., \& Auty, D. (2011). Taper functions for Scots pine (Pinus sylvestris L.) and Sitka spruce (Picea sitchensis (Bong.) Carr.) in Northern Britain. Forestry, 84(1), 49-60. https://doi.org/10.1093/forestry/cpq043

Johnston, J. (1980). Econometric methods. Mossow: Statistika, 444 p. [In Russian].

Kashpor, S. M., \& Strochynskyi, A. A. (Eds). (2013). Forest inventory handbook. Kyiv: Vinichenko, 496 p. [In Ukrainian].

Kershaw, J. A., Ducey, M. J., Beers, T., \& Hush, B. (2016). Forest Mensuration. (5th ed.). Hoboken, NJ, USA: Wiley-Blackwell.

Kofman, B. (1986). Growth and Tree Form. Novosibirsk: Science, 211 p. [In Russian].

Kozak, A. (1988). A variable-exponent taper equation. Canadian Journal of Forest Research, 18(11), 1363-1368. https://doi.org/10.1139/x88-213

Li, R., \& Weiskittel, A. R. (2010). Comparison of model forms for estimating stem taper and volume in the primary conifer species of the North American Acadian Region. Annals of Forest Science, 67(3), 302-302. https://doi.org/10.1051/forest/2009109

Newnham, R. M. (1992). Variable-form taper functions for four Alberta tree species. Canadian Journal of Forest Research, 22(2), 210-223. https://doi.org/10.1139/x92-028

Nikitin, K. E., \& Shvidenko, A. Z. (1978). Methods and Technique of Data Processing in Forestry. Moscow: Lesnaja Promyshlennost, 272 p. [In Russian].

Orlov, M. M. (1929). Forest Mensuration. Leningrad: Lesnoe khoziaistvo i lesnaia promyshlennost, 532 p. [In Russian].

Poudel, K. P., Temesgen, H., \& Gray, A. N. (2018). Estimating upper stem diameters and volume of Douglas-fir and Western hemlock trees in the Pacific northwest. Forest Ecosystems, 5(1). https://doi.org/10.1186/s40663-018-0134-2

$R$ Core Team. (2018). Retrieved from: https://www.r-project.org/

Socha, J. (2002). A taper model for Norway Spruce (Picea Abies (L.) Karst.). Electronic Journal of Polish Agricultural Universities, 5(2). Retrieved from: http://www.ejpau.media.pl/volume5/issue2/ forestry/art-03.html

Svynchyk, V. A., Kashpor, S. M., \& Myroniuk, V. V. (2014). Mathematical Models of Tree Stems Volumes of Main Forest-Forming Species of Ukraine. Scientific Bulletin of National University of Life and Environmental Sciences of Ukraine, 198(2), 58-64. [In Ukrainian].

Zakharov, V. K. (1955). Novel in Methodology of Tree Stem Investigation and Compilation of Volume Tables. Proceedings on Forestry, 4, 21-24. [In Russian].

V. B. Bychenko, V. V. Myroniuk

National University of Life and Environmental Sciences of Ukraine, Kyiv,Ukraine

\section{SOME PECULIARITIES OF STEM TAPER MODELLING OF COMMON OAK TREES}

The paper summarizes the experience of tree stem form investigation; therefore we can draw the conclusion that mathematical modelling of stem profiles overperforms alternative methods for analysing stem taper. Based on the study material collected in oak stands of Dnieper Right-bank Forest-Steppe of Ukraine on 17 temporally sample plots, the relationship of common oak (Quercus robur L.) tree stem form with tree height and diameter at $1.3 \mathrm{~m}$ has been studied. We have conducted both graphical and statistical analyses of Schiffel's form quotients in dependence on tree heights and diameters at breast height. Visual inspection of stem profiles and $t$-test at $5 \%$ significance level have pointed to high variation of stem form for trees having different diameters. Inside height classes differences in taper has not been revealed. Thus, it substantiated the necessity of stem taper modelling of common oak trees regardless of tree height but for three diameter classes such as $20-28 \mathrm{~cm}, 32-40 \mathrm{~cm}$, and $44-64 \mathrm{~cm}$. As a model of stem taper, we have tested two variable-exponent equations by A. Kozak (1988) and R. Newnham (1992). The models were fitted to the test data representing stem measurements of 171 model trees of oak. We have used a $n l s$ (nonlinear least-square regression) algorithm for $\mathrm{R}$ to get estimates of parameters. The R. Newnham (1992) function was fitted using relative diameter and height values while A. Kozak (1988) - absolute ones. Totally, we have developed six taper equations (two models for three diameter classes). The systematical error of both types of equations has been revealed to be nearly equal to zero (0.9-1.7\%) that allowed us to adopt them as appropriate models of stem taper for established diameter classes. The developed models predict diameters of oak tree stems at any height with high accuracy and have small standard error of $1.5-3.2 \mathrm{~cm}$. We have analysed the distributions of residuals of models in dependence of relative tree height and revealed the autocorrelation of residuals of R. Newnham (1992) equation which has also been proved by Durbin-Watson test at $5 \%$ significance level. The test has not indicated the presence of autocorrelation of residuals of A. Kozak (1988) model for any diameter classes of oak trees. As a result, we have adopted A. Kozak (1988) equation as a mathematical model of stem taper and would recommend it for estimation of total and merchantable volume of the oak trees.

Keywords: stem form; taper; taper equation; biometrical parameters; accuracy; adequacy. 